\title{
Evaluation Of Pensi (Corbicula Moltkiana) Fishing Activity In Lake Maninjau, West Sumatera Indonesia
}

\author{
Lukman \\ Research Centre for Limnology, Indonesian Institute of Sciences.
}

Setyobudiandi I.

Department of Aquatic Resources Management,

Faculty of Fisheries and Marine Science, Bogor Agricultural University.

\section{Muchsin I.}

Department of Aquatic Resources Management, Faculty of Fisheries and Marine Science, Bogor Agricultural University.

\section{Hariadi S.}

Department of Aquatic Resources Management, Faculty of Fisheries and Marine Science, Bogor Agricultural University.

\begin{abstract}
Pensi (Corbicula moltkiana) is the name a kind of freshwater mussel, which inhabit the Lake Maninjau, West Sumatra Province, Indonesia. Pensi has been utilized and important for the people in the Lake Maninjau region. The pensi fishing activities continuously will impact to their availability in the future. The purpose of this study is to observe the characteristics of pensi fishing activity in Lake Maninjau. The research conducted at the Maninjau Lake area, District of Tanjung Raya, Agam Regency West Sumatera Province from September 2013 to May 2014. The type of data collected is primary data with a focus on the dimensions and fishing pressure. Measurement methods used are interviews, data collection from fishermen and direct observations in the field. The data collected is then analyzed with descriptive methods. Pensi fishing activities as livelihood relatively available in the region Maninjau, especially for people who have no alternative other business fields. Average catches Pensi by fishermen was 51 liters (L) or $42 \mathrm{~kg}$ per day, and total production for all fishermen in Lake Maninjau region is $750607 \mathrm{~kg}$ (751 tons) per year.
\end{abstract}

KEYWORDS: Corbicula moltkiana, mussel, fishing activity, Lake Maninjau

\section{INTRODUCTION}

Pensi (Corbicula moltkiana) is a local name of a kind of freshwater mussel found in Lake Maninjau, West Sumatra Indonesia. The pensi is spread from Sumatra to Malaysian Peninsular [1], and their existence in Lake Maninjau is quite abundant, especially in the sand substrate, it reach up to $>1300$ ind./ $\mathrm{m}^{2}$ [2]. Currently, exploitation of pensi is a part economic activity for the local community, although it is a relatively small activity compared to other fisheries [3].

In Indonesia, mussel fishing activity in inland waters is very rare. Some areas that utilize freshwater for consumption only in several locations, include $C$. javanica in West Java, Batista violacea var celebensis from river waters in Southeast Sulawesi [4], and B. violacea at mouth of Batang Anay in West Sumatra [5]. Utilization of pensi in Maninjau area, is local but has an important value because it becomes the culinary icon for tourism. Pensi known as a snack food and widely liked by the people of West Sumatra. 
Cathing product as raw pensi and some of them as portions of meat are sold to traders / collectors. Pensi product distribution, beside in local market pensi sold also in several cities around West Sumatra.

As a snack food, pensi is sold in small stores along Maninjau City with the price of a packet that is ready to eat between Rp. 2,000 - Rp. 5.000, has relatively good nutrient, which has high protein content (43.4\% dry weight of meat [mdw]) but with low fat content $(3.4 \% \mathrm{mdw})[6]$.

Pensi fishing activity tend to exploitatively with no rules and restrictions, either the catch size restriction, the size of fishing gear, the time and intensity of its capture. It is necessary to understand the utilization level of pensi in Lake Maninjau so that its availability in nature is maintained. Thus the purpose of this study is to examine the characteristics of pensi fishing activity in Lake Maninjau West Sumatra.

\section{MATERIALS AND METHODS}

The study was conducted from September 2013 to May 2014 in Lake Maninjau, Tanjung Raya sub district, Agam regency of West Sumatra Province. The type of data collected is the primary data related to the fishing intensity, which is evaluated from dimensions and pressure of fising based on the data by the measurement method as can be seen in Table 1 . The level of catch pressure is calculated through direct observation by determining the productivity of catch and catch intensity based on the fishing activity of the fisherman in the field.

Table 1. Data type and methods on determination of pensi exploitation intensity

\begin{tabular}{|c|c|c|c|}
\hline No. & (Data type) & (Units/criteria) & (Methods) \\
\hline \multicolumn{4}{|c|}{ Dimension } \\
\hline & Number of fishermen & Fishermen/village & Interview \\
\hline 2. & $\begin{array}{l}\text { Distribution of fishing } \\
\text { activity }\end{array}$ & Location & Interview \\
\hline 3. & Fishing methods & Pattern of catching & Field observation \\
\hline 4. & Area of fshing activity & $\mathrm{m}^{2}$ & Field observation: \\
\hline & & & $\begin{array}{l}\text { i) Depth profile mapping of coastal area } \\
\text { perpendicular to the beasch, using } \\
\text { Garmin fishfinder and GPS Garmin on } \\
\text { each fixed station; } \\
\text { ii) Beach contour conditions; } \\
\text { iii) Fishing activity. }\end{array}$ \\
\hline \multicolumn{4}{|c|}{ Fishing intensity } \\
\hline 1. & Fishing periods & Days per month & \multirow{2}{*}{$\begin{array}{l}\text { Data collection: } 14 \text { fisherment; } 5 \text { months } \\
\text { Data collection: } 14 \text { fisherment; } 5 \text { months }\end{array}$} \\
\hline & $\begin{array}{l}\text { Fishing frequency on } \\
\text { each area }\end{array}$ & $\begin{array}{l}\text { Rate of visits at each } \\
\text { catch location from } \\
\text { the all locations (\%) }\end{array}$ & \\
\hline 3. & Cach yield & Liter (L) per day & Data collection: 14 fisherment; 5 months \\
\hline & Catch intensity & Hour per day & Calculation \\
\hline 5. & Productivity of area & $\mathrm{L} / \mathrm{m}^{2}$ & Calculation \\
\hline
\end{tabular}

\section{Data Analysis}

The collected data then was analyzed by descriptive method, presented by forming tables and drawings. Fishing method of pensi by fishermen usually use the bottom scoop net or something like kicknets. The fishermen pressed the kick nets onto the substrate followed by distrubing the bottom of lake. Fishing area productivity evaluated from fishing activities observation on some fishermen. The distance of fisherman to scoop the pensi was measured and the catch of pensi was weighed. The data obtained are calculated by the formula:

$$
\mathrm{P}=\mathrm{H} / \mathrm{A}
$$


$\mathrm{P}=$ Productivity of fishing location $\left(\mathrm{L} \mathrm{m}^{-2}\right)$;

$\mathrm{H}=$ The catch of pensi by fisherman (L)

$\mathrm{A}=$ Field area of capture $\left(\mathrm{m}^{2}\right)$

= Distance of scoop disturb the substrate $(\mathrm{m}) \mathrm{x}$ the width of the mouth opening of scoop $(\mathrm{m})$

\section{Dimension of pensi fishing}

\section{RESULTS}

The number of fisherman who catch the pensi from all villages in the surounding of Lake Maninjau was 53 people (Table 2). The distribution of fishing activity covers the northern areas of the lake from Koto Gadang to Sungai Range (S2 - S4), in the east area from Lubuk Anyir to Gasang (S5 - S7), and in south area form Banda Gadang to Muka Jalan (S8 - S11). In western area of the lake, pensi fishing activity were only for their own use (Figure 1).

Table 2. Number of fisherman on each village in shore of Lake Maninjau

\begin{tabular}{|c|c|c|c|c|}
\hline No. & Village & Code and station name & Sub village & $\sum$ fisherman \\
\hline 1 & Koto Malintang & S1; Muko-muko & & 0 \\
\hline \multirow[t]{2}{*}{2} & Koto Gadang/ & S2 ; Rambay & Rambay & 2 \\
\hline & VI Koto & & Akay & 3 \\
\hline 3 & II Koto & S3 ; Muara Tanjung & Koto Tinggi & 8 \\
\hline \multirow[t]{3}{*}{4.} & Bayur & S4 ; Sawah Lie & Sawah Lie & 0 \\
\hline & & S5 ; Lubuk Anyir & Lubuk Anyir & 3 \\
\hline & & S6 ; Lubuk Kandang & Pekandangan & 2 \\
\hline \multirow[t]{3}{*}{5} & Maninjau & S7 ; Bancah & Kubu baru & 1 \\
\hline & & S7 ; Bancah & Penurunan & 2 \\
\hline & & S7 ; Bancah & Gasang & 1 \\
\hline \multirow[t]{2}{*}{6} & Sungai Batang & S8; Banda Gadang & Batung Panjang & 5 \\
\hline & & S8 ; Banda Gadang & Tanjung Sani & 4 \\
\hline \multirow[t]{7}{*}{7} & Tanjung Sani & S9; Pandan & Pandan & 7 \\
\hline & & S10; Batu Nanggay & Galapung & 3 \\
\hline & & S10; Batu Nanggay & Batu Nanggay & 3 \\
\hline & & S11; Muka Jalan & Muka Jalan & 4 \\
\hline & & S12; Dalu dalu & Dalu & 3 \\
\hline & & S13; Sungai Tampang & Sungai Tampang & 2 \\
\hline & Total & & & 53 \\
\hline
\end{tabular}

Source: Primary data were processed, 2013-2014 


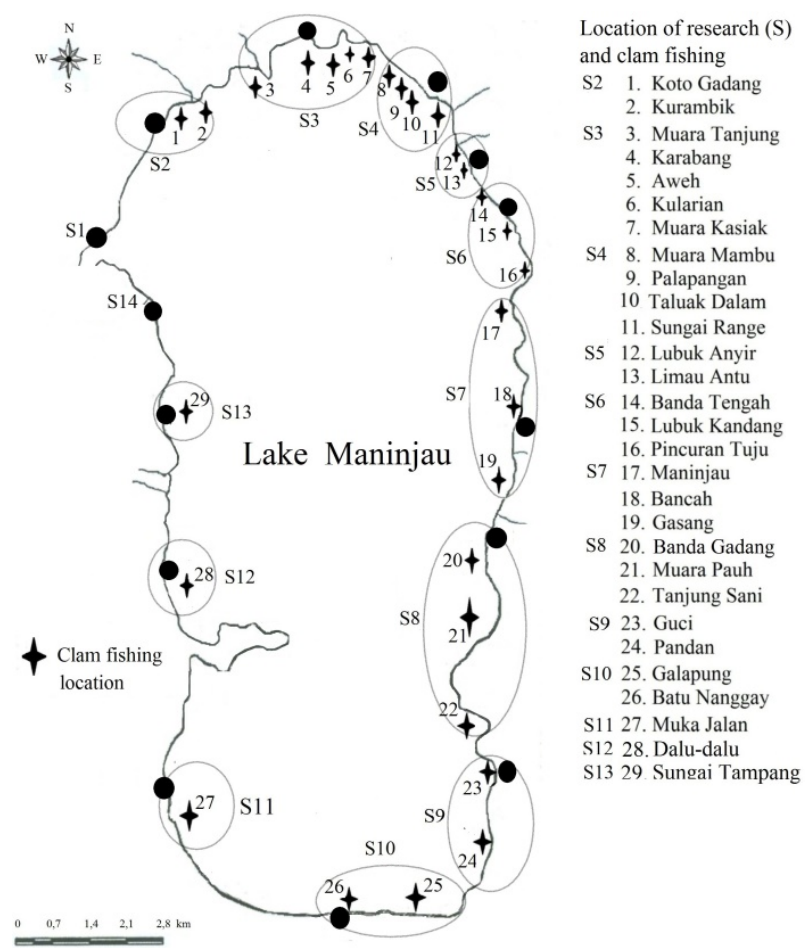

Figures 1. Distribution of pensi catch location in Lake Maninjau

Pensi fishing activity traditionaly using a rake like tool, a gear that is widely used in the past known as "dauh". It has a square rectangular iron frame, a $90 \mathrm{~cm}$ opening of mouth, be equiped with a pocket-shaped net with a mesh $3 / 4$ inches and weighted (Fig. 2; left). The use of "dauh" is pulled towards the beach or pulled from the boat. Right now the most widely used fishing gear is "serok", kick net-like tool, with $60-90 \mathrm{~cm}$ opening of mouth (Figure 2; right)
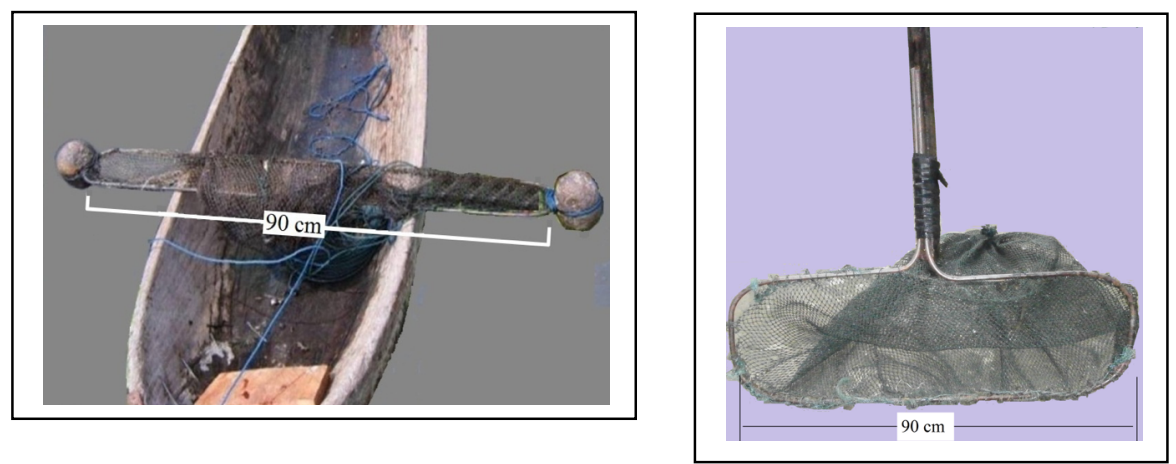

Figures 2. Pensi catching gear: Dauh (left) and serok (right)

The use of the "serok" is done by disturbing the substrate using the foot (Figure 3, left), generally for depths up to one meter, and disturbing the substrate by hand (Figure 3, right), carried out at depths of up to three meters. 


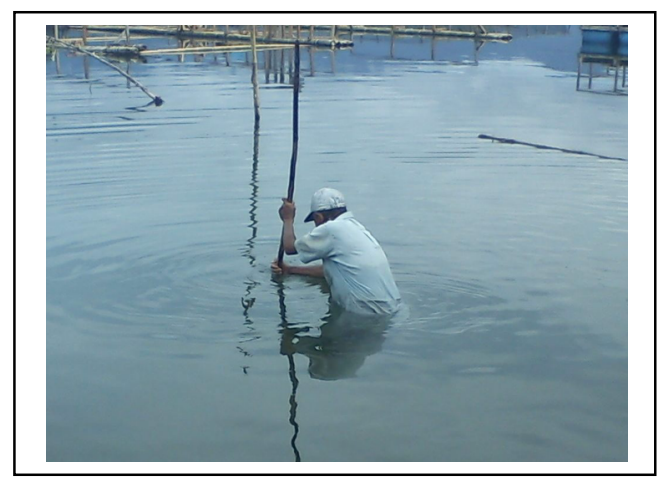

Figures 3. Pensi cathing methods: Substrate disturbation by feet (left) and by hand while diving (right)

The pensi fishing aid apparatus is a fine sieve $(1.5 \times 0.7 \mathrm{~cm}$ mesh size) to separate the pensi from the rock and the small pensi, and the coarse sieve $(1.5 \mathrm{~cm}$ mesh size) is used to separate large pens and small pens.

Based on the lake edge width at the defined station to a depth of $<5 \mathrm{~m}$ (referring to the fishing activity observation) assumed as the pensi habitat as well as long of the shore, the potential habitat area of pensi in Lake Maninjau is 1,105,700 $\mathrm{m}^{2}$ (Table 3). This area does not include locations where there are no catches such as the steeply contoured location on the Sani Peninsula and the location of Hydropower.

The area of pensi habitat when compared to the lake area ( 9.937 .5 ha or $97.375 .000 \mathrm{~m}^{2}$ ) (Fakrudin et al. 2002), is very small, only $1.13 \%$. This condition is related to the depth profile of Lake Maninjau which tend to be steep.

\section{Pensi fishing intensity}

Fishing activity of pensi take place almost every day, some fishermen do not carry out activity only on market days. The number of working days per month ranging from 24-30 days or 28 days on average (Table 4). Thus within one year, fishing activity averaged 336 days. 
Table 3. Pensi potential habitat area in shore of Lake Maninjau

\begin{tabular}{|c|c|c|c|c|c|}
\hline Station & Zone & $\begin{array}{l}\text { Shore line } \\
\text { length }^{1}(\mathrm{~m}) \\
\text { (a) }\end{array}$ & $\begin{array}{l}\text { Width of } \\
\text { shore area }{ }^{2} \\
\text { (m) (b) }\end{array}$ & $\begin{array}{c}\text { Pensi potential } \\
\text { habitat area } \\
\left(\mathrm{m}^{2}\right) \\
(\mathrm{a} \times \mathrm{b})\end{array}$ & $\begin{array}{l}\text { Shore area } \\
\text { condition }{ }^{3}\end{array}$ \\
\hline & Hydropower/Outlet area & 2.000 & ta & tap & Sharp \\
\hline S1 & Muko-muko & 1.000 & 18 & 18.000 & Steep \\
\hline S2-S5 & Rambay - Lb.Anyir & 9.600 & 62 & 595.200 & Gentle \\
\hline S6-S7 & Lb.Kandang-Bancah & 6.900 & 16 & 110.400 & Gentle \\
\hline S8-S9 & Bd.Gadang-Pandan & 8.900 & 21 & 186.900 & Gentle \\
\hline \multirow[t]{2}{*}{ S10-S11 } & Bt.Nanggay - Mk. Jalan & 10.600 & 17 & 180.200 & Steep \\
\hline & Sani peninsular & 5.000 & ta & tap & Sharp \\
\hline S12-S13 & Dalu - S.Tampang & 6.000 & 20 & 12.000 & Steep \\
\hline S14 & Batu Anjing & 3.000 & 10 & 3.000 & Steep \\
\hline
\end{tabular}

Notes: 1) Distance between coordinates of observation point; 2) Width average of lake edge on depth $<5 \mathrm{~m}$ in each observation station in the area; 3 ) See figure 1 ; ta = no data; tap = no pensi capture

Source: Primary data were processed, 2013-2014

Table 4. Number of work days of fisherman on five months observation

\begin{tabular}{ccccccc}
\hline \multirow{7}{*}{$\begin{array}{c}\text { Fisherma } \\
\text { n number }\end{array}$} & 1 & 2 & 3 & 4 & 5 & \\
\cline { 1 - 5 } Average \\
\hline 1 & 26 & 21 & 18 & 31 & 26 & 24 \\
2 & 23 & 31 & 24 & 29 & 30 & 27 \\
3 & 30 & 31 & 28 & 30 & 30 & 30 \\
4 & 31 & 31 & 28 & 31 & 30 & 30 \\
5 & 30 & 29 & 28 & 31 & 30 & 30 \\
6 & 31 & 31 & 28 & 29 & 30 & 30 \\
7 & 28 & 29 & 23 & 27 & 24 & 26 \\
8 & 27 & 29 & 25 & 31 & 30 & 28 \\
9 & 31 & 29 & 27 & 31 & 30 & 30 \\
\hline \multicolumn{2}{c}{ Average } & & & & & 28 \\
\hline
\end{tabular}

Source: Primary data were processed, 2013-2014

Based on number of fishermen who visit to each from total fishing locations scattered around the banks of Lake Maninjau (Figure 1), some of locations have high frequencies. The highest frequency of fishing activity in the north part of the lake was Kularian (12.1\%), in south part of the lake in Banda Gadang (9.8\%) and Tanjung Sani (8.6\%) both at Station of Banda Gadang (S8). Based on the station critertia, the high catching frequency was at Muara Tanjung (S3) (26.5\%), Sawah Lie (S4) (17.4\%) and Banda Gadang (S8) (19.0\%).

The unit of pensi production is a "blek" (cans basket) which has a volume about 20 liters (L), which the size of $1 \mathrm{~L}$ "overflow" to the top. Average daily catch ranged from 1.13 to 4.48 "blek" per day or 23.7 - 90.1 L per day. Spent of fishing activity time between 6 - 8 hours per day (Figure 4). The fishing time seems relatively long, almost a day, but the effective time use is lower. This is includes time to rest and sortir out the pensi from bargage or gravel. 


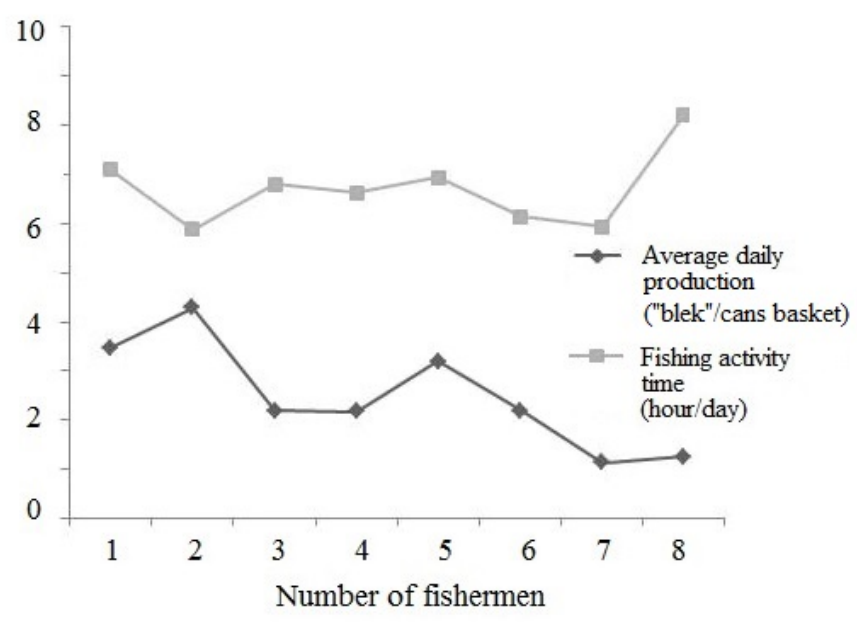

Figure 4. Production and work time of pensi fisherman in Lake Maninjau

Table 5. Characteristic of pensi exploitation area

\begin{tabular}{clcc}
\hline $\begin{array}{c}\text { No.of } \\
\text { fisherman }\end{array}$ & \multicolumn{1}{c}{ Locations } & $\begin{array}{c}\text { Depth of } \\
\text { fishing area }\end{array}$ & $\begin{array}{c}\text { Pensi abundance of fishing area } \\
\left(\mathrm{L} \mathrm{per} \mathrm{m}^{2}\right)\end{array}$ \\
\hline 1. & Pandan & $1.0-3.0$ & 1.444 \\
2. & Galapung & $1.0-40$ & 1.213 \\
3. & Tanjung Sani & $1.0-3.5$ & 0.407 \\
4. & Banda Gadang & $0.5-1.0$ & 0.246 \\
5. & Guci & $0.5-1.0$ & 1.128 \\
6. & Kularian & $1.0-3.5$ & 0.259 \\
7. & Palapangan & $1.0-3.5$ & 0.492 \\
8. & Guci & $1.0-3.5$ & 0.906 \\
9. & Limau Antu & $1.0-3.5$ & 1.852 \\
\hline
\end{tabular}

Source: Primary data were processed, 2013-2014

Based on direct observation of fishing activities at fishing sites, catch product of pensi ranged from 0.26 - $1.85 \mathrm{~L}_{\text {per }} \mathrm{m}^{2}$, lowest in Banda Gadang and highest in Limau Antu (Table 5). The areas with low production ( $<0.5 \mathrm{~L}_{\text {per }} \mathrm{m}^{2}$ ) were Tanjung Sani, Banda Gadang, Palapangan and Kularian, in line with the high of pensi capture frequency. The area with highest product level is in Limau Antu, corresponding to the low catch frequency.

The production value of area will reflect the pensi population condition from each location, and can determine how extent the area exploited. The rate of exploitation of fishing grounds by fishermen in Lake Maninjau ranges from $22-272 \mathrm{~m}^{2}$ per day. With low area productivity, fisherman four requires considerable land to be exploited (Table 6).

The maximum length (anterior-posterior) range of large size pensi (sorted by coarse sieve) from $22.0 \mathrm{~mm}$ (northern part of lake) to $23.66 \mathrm{~mm}$ (southern part of lake). Range length of small sized pensi (passed by coarse sieve) in the south and north part of the lake have the same length ranges, ranging from 11.2 - $17.4 \mathrm{~mm}$ although the proportion of each pensi length range was different (Figure 5).

The proportion of large and small pensi sizes caught by fishermen varies considerably, for large sizes ranging from $28-62 \%$ (Table 7) 
Table 6. Exploitation rate of pensi fishing area in Lake Maninjau

\begin{tabular}{|c|c|c|c|c|}
\hline \multirow{2}{*}{$\begin{array}{l}\text { Fishermen } \\
\text { number }\end{array}$} & \multicolumn{2}{|c|}{ Cath product } & \multirow{2}{*}{$\begin{array}{l}\text { Production of } \\
\text { fishing zone } \\
\text { (Lt per } \mathrm{m}^{2} \text { ) }\end{array}$} & \multirow{2}{*}{$\begin{array}{c}\text { Area exploitation } \\
\text { rate } \\
\left(\mathrm{m}^{2} \text { per day }\right) \\
\end{array}$} \\
\hline & Basket per day & Liter per day & & \\
\hline 1 & 3.48 & 73.07 & 1.44 & 50.6 \\
\hline 2 & 4.30 & 90.20 & 1.21 & 74.4 \\
\hline 3 & 2.18 & 45.88 & 0.41 & 112.7 \\
\hline 4 & 3.19 & 67.05 & 0.25 & 272.5 \\
\hline 5 & 2.19 & 45.95 & 1.13 & 40.7 \\
\hline 6 & 1.13 & 23.74 & 0.26 & 91.5 \\
\hline 7 & 1.27 & 26.63 & 0.49 & 54.2 \\
\hline 8 & 2.20 & 46.11 & \multicolumn{2}{|c|}{ No data } \\
\hline 9 & 1.98 & 41.55 & 1.85 & 22.4 \\
\hline & 2.43 & 51.13 & 0.88 & 89.9 \\
\hline
\end{tabular}

Source: Primary data were processed, 2013-2014

(\%) 50

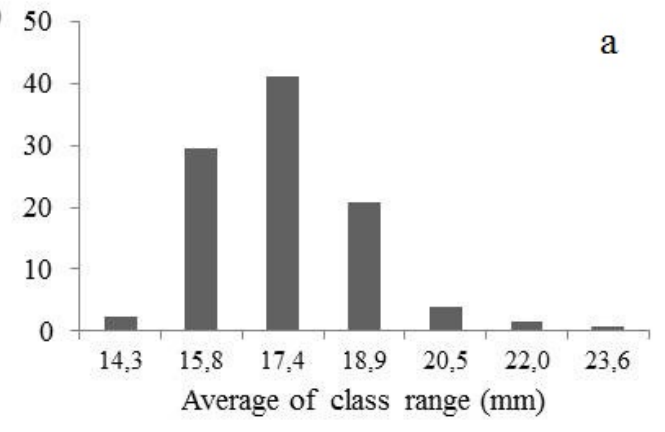

(\%) 50

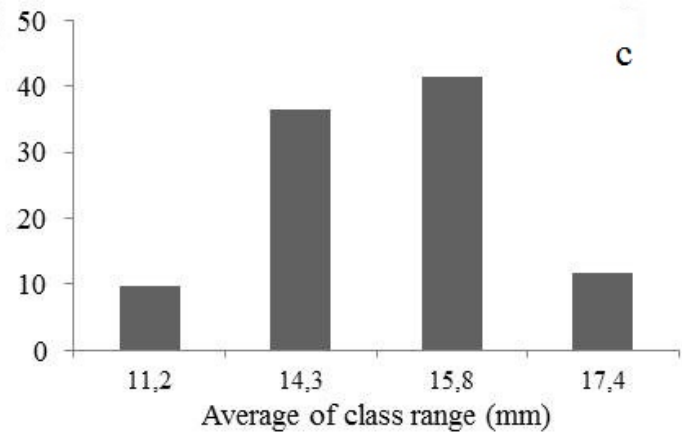

(\%) 50

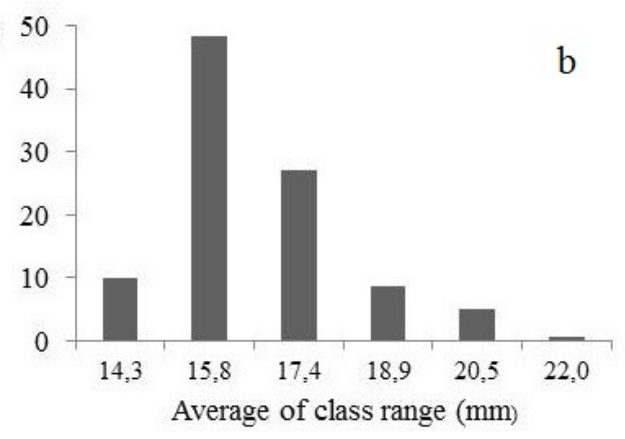

(\%)

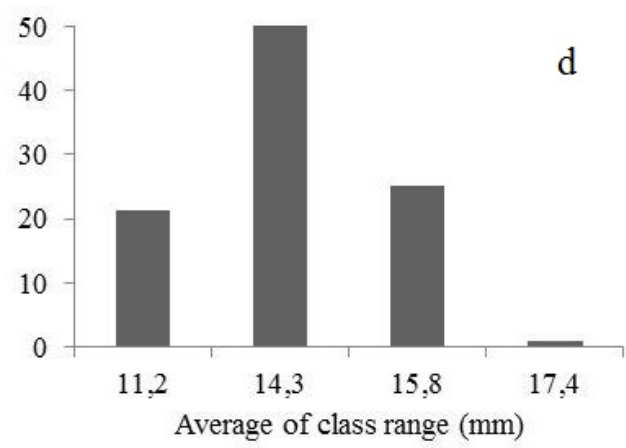

Figure 6. Proportion each average length class range of pensi:

Big size (Above) in lake south zone (a) and in lake north zone (b);

Small size (Below) in lake south zone (c) and in lake north zone (d).

Table 7. Weight proportion (\%) for big and small size pensi

\begin{tabular}{|c|c|c|c|c|c|c|}
\hline \multirow[b]{2}{*}{ Pensi size } & \multicolumn{5}{|c|}{ Exploitation Zone } & \multirow[b]{2}{*}{ Average } \\
\hline & $\begin{array}{c}\text { Banda } \\
\text { Gadang }\end{array}$ & $\begin{array}{c}\text { Batu } \\
\text { Nanggay }\end{array}$ & Pandan & $\begin{array}{c}\text { Sawah } \\
\text { Lie }\end{array}$ & $\begin{array}{c}\text { Muara } \\
\text { Tanjung }\end{array}$ & \\
\hline Big & 61.7 & 34.1 & 28.0 & 43.4 & 35.9 & 40.6 \\
\hline Small & 38.3 & 65.9 & 72.0 & 56.6 & 64.1 & 59.4 \\
\hline
\end{tabular}

Source: Primary data were processed, 2013-2014 


\section{DISCUSSION}

Pensi fishery is a small-scale (artisanal) fishery in Lake Maninjau, but has become an important economic resource for marginal communities on arround the lakes, as a livelihood alternatives. Utilization of pensi as mollusk biota is usually a small scale fishery. Utilization of freshwater pensi Polymesoda solida though a major fishery resources in Cienaga Poza Verde, Colombia Caribbean, but it turns out only as a small fishery of 80 fishermen [7]. Similarly, the catching of Amiantis purpurata pensis in Patagonia Argentine and the other types of mollusks fisheries only a small-scale fishing activity [8][9].

Areas that have high catching intensity in Lake Maninjau Lake, such as Kularian, Palangan and Banda Gadang, this is mainly related to proximity to fishermen residence, the open enough edge with no cage aquaculture activities and has sand as dominant substrate that supports the pensi population.

Many of the clam population are characterized by irregular (spasmodic) biomass pulses [8]. Consequently, their fisheries are dominated by opportunistic behavior of fishermen following unexpected pulses. Fishermen naturally tend to catch in the most profitable places.

The number of pensi fishermen in Lake Maninjau was much lower than that of pokea mussel (B.violacea var. celebesensis) fishermen in Pohara River Southeast Sulawesi (167 people) [10]. The average daily catch of Lake Maninjau fishermen is $51 \mathrm{~L}$ per day which, if converted to weight $(1 \mathrm{~kg}=0.824 \mathrm{~L}$, direct measurement in fishermen), is approximately $42.15 \mathrm{~kg}$ per day. This result is relatively high when compared with the catch of pokea in Pohara River, which ranges from 25 - $50 \mathrm{~kg}$ per fisherman with the frequency of taking twice a week [4].

Considering the pensi product average $42.15 \mathrm{~kg}$ per fisherman/day and the number of fisherman was 53 people, therefore the total catch of pensi was $2234 \mathrm{~kg}$ per day. The assumtion that on a year is 336 days, therefore the total production of pensi was 750,6 $\mathrm{kg}$ (751 tons) per year. The pensi catch was much higher than the freshwater mussel Polymesoda soline captured at Cienaga (Columbian Caribbean) which reaches an average of $314.5 \mathrm{~kg}$ net weight of without shell and is an business of 42 fishermen with operating 6 hours per day from 20 days per month [7].

Reffering to the report of West Sumatra Provincial Fishery Agency on fish catch production in Lake Maninjau on 2003 which reached 111.7 tons (Triyanto, Researcher of Limnology Research Center, Personal Communcation), indicated that the pensi production much more than fish prodution.

Currently pensi fishing activity is limited to three meters depth of the lake's edge, as decreasing of pensi stock at a depth of $>5 \mathrm{~m}$. Based on previous reports, pensi was still found at a depth of $10 \mathrm{~m}$ with an abundance of 667 individu / $\mathrm{m}^{2}$ [11]. Activity of cage aquaculture play a role in decreasing the water quality of Lake Maninjau [12][13][14][15], and have impact on deteration the bottom of lake, as pensi habitat. Cage aquaculture waste accumulation continuously worsened the habitat of pensi. In area of the cage aquaculture in Penghu Islands, Taiwan, found that sedimentation and organic loading levels are significantly higher [16].

With regard to the impact of cage aquaculture activity on the pensi population, it is necessary to consider to limiting cage area in Lake Maninjau. In Australia coastal area has been implemented regulation to setting commercial and non-fishery fishing (catching) areas partly to reduce social conflict between different user groups [17]. 
Capture of pensi which in two categories, large and small, needs to be observed carefully. On fishing activity of Donax deltoids, in New South Wales Australia with two different size targets, commercial and recreation, it makes difficult to balance the management needs of both sectors. This is related to the stock assesment in their habitat, and their population is susceptible to the high variation of recruitmen and abundance distribution [18].

Pensi fisheries in Lake Maninjau currently must managed well to maintain the sustainability. It was proposed that fishery resources in shallow water are important, but usually exploited without a management plan [19]. Fishermen tend to increase their fishing effort as long as profitable, resulting in excessive exploitation until the net income of fishermen reaching zero. Mussels as one of the fishery resources, especially in coastal habitats has been widely exploited and declined in population [17][20]. In Lake Lindu, Indonesia, mussel of $C$. lindoensis, in the past were abundant and became a source of community protein, right now hard to find it [21].

Efforts to conserve the mussle resources have been largely undertaken. This is one of strategies to spase closure, which means to protect wild aquatic organisms population from human exploitation [22] [23]. It was argued that although partial shoreline closure for mussel conservation does not always have significant long-term impact, due to their mobility and environmental conditions [17]. However, it is argued that the closure of territories for commercial fisheries may provide important protection for some mussel at each coast and reduce the impact of such utilization.

Shell management strategies should not only target economically-valued resources and focus on the biological aspects of the population in use, but they should also take into account socioeconomic information such as user profiles, behavior, consumption characteristics and their perceptions of threats to their activities [24]. However, in many instances, ecological data such as knowledge of growth, reproduction, production and shell biomass are needed to build the management plan [19].

\section{CONCLUSION}

Pensi fishing activity in Lake Maninjau spread throughout almost the lake edge to three meters depth, providing alternative livelihoods for the Maninjau people. The northern and eastern edge of the lake is an area with high fishing activity, related to shore conditions and population distribution. With the number of fishermen around 50 people and the pensi average yield 42 $\mathrm{kg}$, the total pensi catch product can reach 751 tons per year.

\section{References}

Djajasasmita, M. (1977). An annotated list of the species of the genus Corbicula form Indonesia (Mollusca: Corbiculidae), Bulletin Zoologisch Museum-Universiteit van Amsterdam 6 (1), 1 - 9

Lukman, Isdradjad, S., Muchsin, I., \& Hariyadi, S. (2015). Distribusi kelimpahan pensi (Corbicula moltkiana, Prime 1878) di Danau Maninjau. (Abundance distribution of Pensi [Corbicula moltkiana, Prime 1878] in Lake Maninjau). Limnotek 22(1), 12-21 (In Indonesian)

Anonymous. (2009). Laporan Produksi Perikanan Kabupaten Agam. Pembesaran Ikan di Keramba Jaring Apung Tahun 2008. (Report of Fisheries Production in Agam District. Fish Growthout in Cage Aquaculture on 2008). Marine and Fisheries Board of Agam Distric-West Sumatra Province. (Unpublished) (In Indonesian)

Bahtiar. (2012). Studi bioekologi dan dinamika populasi pokea (Batista violacea celebensis, Martens 1897) yang tereksploitasi sebagai dasar pengelolaan di Sungai Pohara Sulawesi Tenggara. (Bioecology and population dynamic study as a management basis of Pokea [Batissa violacea var.celebensisvon Martens, 1897] exploited in Pohara River Southeast Sulawesi. Disertation. Bogor Agriculture University (In Indonesian)

Putri, R. E. (2005). Analisis populasi dan habitat: Sebaran ukuran dan kematangan gonad kerang lokan Batissa violacea Lamarck, 1818 di Muara Sungai Batang Anay Padang, Sumatera Barat. (Habitat and population analysis: 
Distribution the size and gonad maturity of clam Batissa violacea Lamarck, 1818 at Batang Anay estuary). Tesis. Bogor Agriculture University. (In Indonesian).

Tanjung R.L. (2013). Kandungan gizi dan nilai ekonomis pensi, tutut dan Cherax dari Danau Maninjau. (Nutritional content and economic value of pensi, tutut and Cherax from Lake Maninjau). National Seminar on Food, Drug and Environmental Research for Health. Program Studi Kimia FMIPA Universitas Pakuan Jurusan Kimia FMIPA Universitas Padjadjaran. (In Indonesian).

Rueda M \& H-Jorg U. (1998). Population dynamics and fishery of the fresh-water clam Polymesoda solida (Corbiculidae) in Cienaga Poza Verde, Salamanca Island, Colombian Caribbean. Fisheries Research 39, 75-86

Morsan E. (2007). Spatial pattern, harvesting and management of the artisanal fishery for purple clam (Amiantis purpurata) in Patagonia (Argentina). Ocean \& Coastal Management 50, 481-497

Narvarte, M., Gonzalez, R., \& Filippo, P. (2007). Artisanal mollusk fisheries in San Matıas Gulf (Patagonia, Argentina): An appraisal of the factors contributing to unsustainability. Fisheries Research 87, 68-76.

Bahtiar. (2005). Kajian populasi pokea pokea (Batista violacea celebensis, Martens 1897) di Sungai Pohara Kendari, Sulawesi Tenggara (Population study of poke, Batista violacea celebensis, Martens 1897 on Pohara River, Kendari Southeast of Sulawesi). Tesis. Bogor Agricultural University. (In Indonesian)

Sudarso J. (2002). Struktur komunitas makrozoobentos di Danau Maninjau (Macrozoobentos community structure in Lake Maninjau). Internal report. Pusat Penelitian Limnologi-LIPI. (Unpublished). (In Indonesian)

Sulawesty F, Sutrisno, Hamdani A, Triyanto. (2011). Kondisi kualitas air beberapa daerah pemeliharaan ikan karamba jaring apung di Danau Maninjau (Water quality condition at some cage aquaculture area in Lake Maninjau). Limnotek 18(1), 38 - 47 (In Indonesian).

Lukman. (2012). Stratification patterns as "Tubo Belerang" indication in Lake Maninjau. Proc. Inter. Conf. on Indonesian Inland Waters III (pp. 115-120). Palembang, November $8^{\text {th }}, 2012$. The Agency for Marine and Fisheries Research and Development, Res. Center for Fisheries Management and Fish Res. Cons.

Lukman, Sutrisno, \& Hamdani, A. (2014). Fluktuasi oksigen terlarut di kawasan karamba jaring apung di Danau Maninjau dan hubungannya dengan ketersediaan klorofik dan bahan organic (Dissolved oxygen fluctuation in floating net cage area of Lake Maninjau related to chlorophyll and organic matter). Limnotek 21(1), 30 - 40.

Lukman, Isdradjad, S., Muchsin, I., \& Hariyadi, S. (2015). Impact of cage aquaculture on water quality condition in Lake Maninjau, West Sumatera Indonesia. Intern. J. of Sci: Basic and Appl. Res. (IJSBAR), 23 (1), 120 - 137

Huang, Y.C.A, S.C. Huang, H.J. Hsieh, P.J. Meng and C.A. Chen. (2012). Changes in Sedimentation, Sediment Characteristics, and Benthic Macrofaunal Assemblages around Marine Cage Culture under Seasonal Monsoon Scales in a Shallow-water Bay in Taiwan. Journal of Experimental Marine Biology and Ecology, 422-423: 55 - 63

Gray CA. (2016). Assessment of spatial fishing closures on beach clams. Global Ecology and Conservation 5, 108117.

Murray-Jonesa S \& Steffe AS. (2000). Comparison between the commercial and recreational fisheries of the surf clam, Donax deltoids. Fisheries Research 44, 219-233.

Hueda-Jorg U. (1998). Description and management of a clam fishery Gari solida, Psammobiidae from Bahıa Independencia, Peru (14ºS). Fisheries Research 35, 199 - 207

Ortega L, Castilla JC, Espino M, Yamashiro C, Defeo 0. (2012). Effects of fishing, market price, and climate on two South American clam species. Mar.Ecol. Prog. Ser. 469, 71-85.

Djajasasmita, M. (1975). On the species of the genus Corbicula from Celebes, Indonesia. Bulletin Zoologisch Museum-Universiteit van Amsterdam 4 (10), 84-87

Lubchenco J, Palumbi SR, Gaines SD, Andelman S. (2003). Plugging a hole in the ocean: the emerging science of marine reserves. Ecol. Appl. 13, S3-S7.

Lester S, Halpern BS, Grorud-Colvert K, Lubchenco J, Ruttenberg BI, Gaines SD, Airamé S, Warner RR. (2009). Biological effects within no-take marine reserves: a global synthesis. Mar. Ecol. Prog. Ser. 384, 33-46.

Turraa A, Xaviera LY, Pomboa M, Camila de Carvalho P, Denadai MR. (2016). Assessment of recreational harvesting of the trigonal clam Tivel amactroides: Socioeconomic aspects and environmental perception. Fisheries Research 174, 58-67 